\title{
Identifying Superior Parents and Recombinants in Rice (Oryza sativa L.) under Salt Affected Soil
}

\author{
S.P. Maurya*, O.P. Verma, P.K. Singh, A.K. Singh and Jyoti Verma \\ Department of Genetics and Plant Breeding, N D University of Agriculture and Technology \\ Kumarganj, Faizabad-224229, (UP), India \\ *Corresponding author
}

\section{A B S T R A C T}

A field experiment with fifty three diverse genotypes (thirty six hybrids and their fifteen parents along with two checks) were evaluated following line $\times$ tester analysis for twelve characters under sodic soil $\left(\mathrm{pH}=9.2, \mathrm{EC}=2.21 \mathrm{dSm}^{-1}\right.$ and $\left.\mathrm{ESP} 45 \%\right)$. The experiment was conducted under irrigated condition in Randomized Block Design with three replications during Kharif, 2015. The $36 \mathrm{~F}_{1} \mathrm{~s}$ were generated by crossing three testers with twelve lines during Kharif, 2014. Twelve plant characters viz., days to 50\% flowering, flag leaf area $\left(\mathrm{cm}^{2}\right)$, plant height $(\mathrm{cm})$, panicle bearing tillers per plant, panicle length $(\mathrm{cm})$, spikelets per panicle, grains per panicle, spikelet fertility (\%), test weight (g), biological yield per plant

\begin{tabular}{|c|}
\hline Keywords \\
\hline $\begin{array}{l}\text { Superior parents, } \\
\text { Recombinants, } \\
\text { Rice, Soil. }\end{array}$ \\
\hline Article Info \\
\hline $\begin{array}{l}\text { Accepted: } \\
\text { 17 October } 2017 \\
\text { Available Online: } \\
\text { 10 December } 2017\end{array}$ \\
\hline
\end{tabular}
$(\mathrm{g})$, harvest-index $(\%)$, and grain yield per plant $(\mathrm{g})$ were studied in the experiment. The analysis of variance for combining ability revealed high significant mean squares due to lines $\times$ tester interactions indicating the preponderance of non-additive gene effects for all the characters. The estimates of sca variance were higher than the corresponding estimates of gca variance for all the characters and values of average degree of dominance were more than unity $(>1)$ revealing over dominance for all of the characters. The predictability ratio was less than one for all the characters further supported the preponderance of nonadditive gene action. For days to $50 \%$ flowering, panicle bearing tillers per plant, spikelet fertility and harvest index; the predictability ratio could not be estimated due to negative value of gca variance for such estimates also indicated the importance of non-additive gene action in the inheritance of these characters under sodic soil condition. On the basis of general combining ability effects, IR12T193, NDRK 50051, NDRK 50060, and IRRI123 were identified as good general combiners for yield and several other important traits to emerge as valuable parents for hybridization programme for obtaining high yielding hybrid or pure line varieties for sodic soil condition. Five crosses viz., NDRK 50037 x CSR 28, IR79156 x IRRI123, NDRK 50051 x FL 478, NDRK 50058 x FL 478, and NDRK 50060 $\mathrm{x}$ IRRI123 showed significant and positive sca effects for grain yield per plant as well as some other yield components. Hence, attention should be given to these five crosses for further utilization in breeding programs for isolating high yielding genotypes to sustain the production and productivity of salt affected soil.

\section{Introduction}

Rice (Oryza sativa L., $2 \mathrm{n}=24$ ) belongs to the family Poaceae (Graminae). Rice has two cultivated and 22 wild species. The cultivated species are Oryza sativa and Oryza glaberrima. Oryza sativa is grown in all over rice growing countries of the world, while 
Oryza glaberrima has been cultivated in west Africa for last 3504 years(Anonymous, 2001). Rice is a staple food of developing world as well as majority of the worlds, human population. Rice occupies a pivotal place in Indian agriculture as staple food for more than $70 \%$ of population and a source of livelihood for about 120-150 million rural households. It amounts for about $43 \%$ of total food grain production and 55\% of cereal production in the country. Rice is primarily a high energy or high caloric food. It contains less protein than wheat. Oryza sativa is a diploid species having 24 chromosomes. The Oryza sativa varieties are commonly grouped in to three subspecies namely: indica, japonica and javanica.

Rice crop needs a hot and humid climate. It is best suited to region which has high humidity, prolonged sunshine and an assured supply of water. The average temperature required throughout the life period of the crop ranges from 21 to $37^{\circ} \mathrm{C}$. At the time of tillering, the crop requires a high temperature for growth. Temperature requirement for blooming ranges from 26.5 to $29.5^{\circ} \mathrm{C}$. At the time of ripening, the temperature should be between 20 to $25^{\circ} \mathrm{C}$. Photoperiodically, rice is a short day plant; however, there are some varieties which are non-sensitive to photo periodic condition.

Rice is grown under different agro-climatic conditions and production systems. Rice is the only the cereal which can be grown successfully in standing water. It has been estimated that about 57 per cent of rice is grown on irrigated land; 25 per cent on rainfed lowland; 10 per cent on the upland; 6 per cent in deep water and 2 per cent in tidal wet land. Paddy is a field of aquatic biodiversity, in which many of them can be used as means to incorporate protein in to the diets of poor and malnourished people in low and middle income (Anonymous, 2004). Rice is the most important staple food crop of the world. It is the principal food of half of the world's human population habitating the humid tropics and subtropics. Rice is cultivated worldwide over an area of about 156.68 million hectare with an annual production of about 680.19 million tonnes with an average productivity of 5.15 tonnes per hectare (Anonymous, 2014). India is the largest rice growing country, while China is the largest producer of rice. In India, during 2014-15 the rice crop had production of 103.04 million tonnes. However, in Uttar Pradesh it was grown on 5.09 million hectare with production of 15.30 million tonnes. The average productivity of Uttar Pradesh is 2573 $\mathrm{kg} / \mathrm{ha}$ which is more than the national average productivity (Anonymous, 2014). Soil salinity negatively affects agricultural production worldwide (FAO, 2014).

Protein content of milled rice is 6-7 per cent, rice however, compares favorably with other cereals in amino acid content. The biological value of protein is high, the fat content of rice is low (2.0-2.5\%) and much of the fat is lost during milling. Rice contains a low percentage of calcium (Ca). Rice grain contains as much B group vitamin as wheat. Milled rice losses valuable proteins, vitamins and minerals in the milling process during which embryo and aleurone layer are removed and much of the loss of nutrients can be avoided through parboiling process. The by-products of rice milling are used for a variety of purposes. Rice bran is used as cattle and poultry feed. Rice hull can be used in manufacture of insulation materials, cement, cardboard and as a litter in poultry keeping. Rice straw can be used as cattle feed as well as litter during winter.

Rice can be grown in many environments, so it has many characteristics making one variety more popular in one region of the world than another. The dominance of salt water across 
the surface of the earth has led to the widespread occurrence of salt affected soils and salt tolerant plants (halophytes) have evolved to grow on these soils. In Uttar Pradesh, about 13.0 lakh ha land area is salt affected, since salinity is an over present threat to agriculture, especially in areas where secondary salinization has developed through irrigated or deform situation.

Although, the average productivity of rice is much lower in India than the average productivity at world level, The development of high yielding, widely adapted pure line rice varieties coupled with advances in production technology in past five decades has enabled us to cope up with the demand of rice to a satisfactory level. However, rapidly increasing demand due to ever increasing Indian population has forced us to search for another quantum jump in rice productivity. The projection of India's rice production target for 2020 AD is 115-120 million tonnes, which can be achieved only by increasing the rice production by over 2.0 million tonnes per year in this decade. This has to be done against the backdrop of diminishing natural resource bases like land, labour and water, which is a huge challenge (Subaiah, 2006). Considering the rapidly decreasing availability of agricultural land due to urbanization and industrialization, utilization of different eco-systems and under exploited stress environments for rice production would be needed. Every year more and more land is becoming non-productive because of salt accumulation in soil in coastal as well as certain inland saline tracks. Salinity is a serious problem affecting $1 / 3$ of all irrigated land in the world. Nearly, 6.73 $\mathrm{M}$ ha of soil in India is salt affected and categorized into two broad groups' alkaline and saline soils. Recent estimates indicate that more than 1.5 $\mathrm{M}$ ha of salt affected area has been reclaimed and is contributing about 10 million tonnes additional food grains to the central pool. At present, in Indo-gangatic plains in India, a total of $2.348 \mathrm{M}$ ha area is salt affected in which UP has share of $1.37 \mathrm{M}$ ha. Thus, adoption of high yielding rice varieties to various stress environments and underutilized lands such as salt affected soil would be important strategy to meet challenges.

For the development of high yielding pure line as well as hybrid varieties in rice or any crop, the information on various genetic aspects of important plant characters is essential for planning and execution of a successful breeding programme. The understanding of gene actions involved in expression of important plant characters and direct and indirect selection parameters of agronomically important traits help in deciding the type of variety to be developed and the breeding methodology to be followed in a particular situation. In order to develop high yielding pure line or hybrid varieties, it is essential to screen germplasm lines for combining ability. The information provided by combining ability analysis not only helps in discriminating the superior parents for use in hybridization programme and identification of crosses of higher genetic worth for further exploitation but also reveals the nature of gene action governing the characters. The combining ability analysis following line $\mathrm{x}$ tester mating design proposed by Kempthorne (1957) was employed to obtain information on above mentioned aspects.

\section{Materials and Methods}

The experiment was carried out at the Department of Genetics and Plant Breeding Research Farm of N.D. University of Agriculture and Technology, Narendra Nagar (Kumarganj), Faizabad. The crosses were made during Kharif, 2014 and the hybrids along with parental lines and check varieties were evaluated during Kharif, 2015. Geographically this place is located in 
between $26.47^{0} \mathrm{~N}$ latitude, $82.12^{0} \mathrm{E}$ longitude and at an altitude of 113 meters above from mean sea level. This area falls in sub-tropical zone (Indo-gangatic plain) and the soil texture is characterized by silty loam in nature having $9.2 \mathrm{p}^{\mathrm{H}}, 2.21 \mathrm{dSm}^{-1} \mathrm{EC}, 45 \mathrm{ESP}$ and $0.40 \%$ organic carbon. The climate of district Faizabad is semi-arid with hot summer and cold winter.

Three testers (male) viz., CSR 28, IRRI123, FL 478 were crossed with 12 diverse lines (female) viz., IR12T193, IR12T127, NDRK 50031, NDRK 50036, NDRK 50037, NDRK 50051, NDRK 50055, NDRK 50058, NDRK 50060, NDRK 50063, Narendra Usar 2009 to generate $F_{1 \mathrm{~s}}$ following a line $\times$ tester mating design.

\section{Results and Discussion}

The understanding of inheritance of various characters and identification of superior parents are important pre-requisites for launching an effective and efficient breeding programme (Dhillon, 1975). It is not always necessary that parents with high mean performance for yield and other traits would produce desirable $\mathrm{F}_{1} \mathrm{~s}$ and/or segregants. The selection of a few parents having high genetic potential as per breeding objectives is essential because analyzing and handling of very large number of crosses resulting from numerous parents available in collections of a crop would be an impractical and perhaps impossible task. The concept of combining ability has assumed great importance in plant breeding as an effective means of selecting potential parents for hybridization and specific crosses for further exploitation. From the genetic point of view, GCA measures additive gene effects and the SCA measures non additive gene effects including dominance and epistasis. This information on the nature of the gene action present in the population would help to determine an appropriate breeding strategy. Among the various techniques of combining ability analysis, line $\times$ tester analysis (Kempthorne, 1957) has been widely utilized for screening of germplasm to identify valuable donor parents and promising crosses in many crops including rice. Wei et al., (2004); Verma and Srivastava (2004); Panwar (2005); Pradhan et al.,(2006); Ahangar et al., (2008); Saidaiah et al., (2010); Sanghara and Hussain (2012); Gopikannan and Ganesh (2013); Tiwari et al., (2014) and S. Prasad et al., (2015).

The present study, therefore, aims to study the combining ability of parents and crosses and gene action for grain yield per plant and its components by line $\times$ tester technique under salt affected soil. The important findings of the analysis are discussed below:

\section{Gene action and components of genetic variance}

The analysis of variance for combining ability for twelve characters and estimates of components of genetic variance and other genetic parameters are given in Table 1. In the present study, the analysis of variance for combining ability revealed highly significant mean squares due to lines $\times$ tester interactions for all the characters under study, representing importance of specific combining ability and non-additive gene effects. The above discussion suggests occurrence of nonadditive gene effects for majority of the characters. Estimates of sca variance were higher than the corresponding estimates of gca variance for all of the traits. The values of degree of dominance were more than unity (>1) revealing over dominance for all the characters. The predictability ratio was lesser than one for all the characters studied. For days to $50 \%$ flowering, panicle bearing tillers per plant, spikelet fertility and harvest index, the predictability ratio could not be estimated due to negative value of gca variance for 
those characters indicated importance of nonadditive gene action in the inheritance of these characters. The predictability ratio less than one also suggested the predominance of non-additive gene effects for all the characters. The importance of additive as well as non-additive gene effects with predominance of non-additive gene effects in inheritance of grain yield and yield components of rice has also been reported earlier by Verma and Srivastava (2004); Punitha et al., (2004); Pradhan et al., (2006); Saleem et al., (2010); Saidaiah et al., (2011); Gopikannan and Ganesh (2013) and S. Prasad et al., (2015) and Archana Devi et al., (2017).

The predominance of non-additive gene effects representing non-fixable dominance and epistatic components of genetic variance indicated that maintenance of heterozygosity would be highly fruitful for improving the grain yield. Hence, the suitable breeding strategy for attaining high yield would be the full or partial exploitation of heterosis through development of hybrid cultivars for salt affected soil. Since, the technology for development of hybrid rice varieties for commercial purposes is being widely and successfully used in different countries including India, it is recommended to explore possibility of isolating high yielding commercial hybrids utilizing the materials of the present investigation. The non-additive gene effects may also be exploited to some extent for improving the characters by resorting to breeding methods such as biparental mating followed by recurrent selection and population improvement methods as suggested by Jensen (1970) and Redden and Jensen (1974).

\section{Heritability in narrow sense}

Estimates of heritability in narrow sense reflecting the importance of fixable (additive) gene effects has been given in Table 1 .
Variable estimates were observed in different traits. High estimates of narrow sense hertitability were observed for GP, SP, PL and $\mathrm{PH}$, indicating the preponderance of additive gene action.

Low estimate of narrow sense heritability were recorded for majority of the yield and component traits in the present study to emerge as poor index for improvement through selection. Hence, heterosis breeding is suggested to develop high yielding hybrids for different ecosystems with special reference to soil affected soil.

High to low estimates of narrow sense heritability has also been reported by Verma and Srivastava (2004); Vijayalakshmi et al., (2008); Seyoum et al., (2012); Basavaraja et al.,(2013); Kumar and $\operatorname{Verma(2015)}$ and Ashish et al., (2016) for different characters in rice.

\section{General combining ability}

For illustrating genetic worth of parents for hybridization programme, the general combining ability (gca) effects of 15 parents (12 lines +3 testers) for twelve characters are listed in Table 1, while the parents exhibiting significant gca effects for different characters are listed in Table 2.

The significant and positive gca effects for grain yield per plant were exhibited by the lines, viz., IR12T193, NDRK 50051, NDRK 50060, while IRRI123 (tester) was found to be good general combiners for grain yield per plant. The best general combiner parent for grain yield per plant, IR12T193 also emerged as good general combiner for early flowering. panicle bearing tillers per plant, spikelets per panicle, grains per panicle, biological yield per plant, and harvest index but it was poor general combiner for flag leaf area, plant height spikelet fertility and test weight. 
Table.1 Analysis of variance for combining ability and genetic components of variance for 12 traits in rice under salt affected soil

\begin{tabular}{|c|c|c|c|c|c|c|c|c|c|c|c|c|c|}
\hline Source of variation & Df & D50F & FL & $\mathbf{P H}$ & PBTP & PL & SP & GP & SF & BYP & H.I & TW & GYP \\
\hline Lines & 11 & 5.57 & 63.14 & 173.44 & 7.57 & 5.92 & 780.12 & 802.20 & 8.04 & 173.66 & 9.57 & 13.15 & 35.82 \\
\hline Testers & 2 & 6.87 & 64.49 & $915.75^{*}$ & 10.66 & $33.54^{*}$ & $4219.36^{*}$ & $3613.36^{*}$ & 2.06 & 292.64 & 0.62 & 6.49 & 42.26 \\
\hline Lines $\times$ Testers & 22 & $6.97 * *$ & 29.62 & $188.84 * *$ & $15.05^{* *}$ & $6.59 * *$ & $819.46^{* *}$ & $712.95 * *$ & $7.49 * *$ & $124.17 * *$ & $8.01 * *$ & $9.39 * *$ & $22.75^{* *}$ \\
\hline Error & 70 & 1.98 & 1.28 & 4.29 & 2.04 & 1.64 & 10.64 & 9.132 & 2.44 & 1.09 & 0.78 & 0.08 & 0.36 \\
\hline Variance GCA & & -0.03 & $1.51 * *$ & $15.81 * *$ & -0.26 & $0.58 * *$ & $74.67 * *$ & $66.43 * *$ & -0.10 & $4.84 *$ & -0.12 & 0.02 & $0.72 *$ \\
\hline Variance SCA & & $1.58 * *$ & $9.52 * *$ & $61.71 * *$ & $4.37 * *$ & $1.72 * *$ & $270.18 * *$ & $234.83 * *$ & $1.77 * *$ & $40.90 * *$ & $2.40 * *$ & $3.07 * *$ & $7.48 * *$ \\
\hline Degree of Dominance & & 4.88 & 1.77 & 1.39 & 2.88 & 1.21 & 1.34 & 1.32 & 2.85 & 2.05 & 3.04 & 8.24 & 2.27 \\
\hline Predictability Ratio & & $@$ & 0.24 & 0.33 & $@$ & 0.40 & 0.35 & 0.36 & $@$ & 0.19 & $@$ & 0.01 & 0.16 \\
\hline Additive variance & & $@$ & 3.03 & 31.62 & $@$ & 1.16 & 149.35 & 132.87 & $@$ & 9.68 & @ & 0.04 & 1.44 \\
\hline Dominance variance & & 1.58 & 9.52 & 61.71 & 4.37 & 1.72 & 270.18 & 234.83 & 1.77 & 40.90 & 2.40 & 3.07 & 7.48 \\
\hline Heritability in Narrow & ense & $@$ & 23.53 & 33.43 & $@$ & 34.68 & 35.35 & 35.68 & @ & 18.97 & @ & 1.43 & 16.02 \\
\hline
\end{tabular}

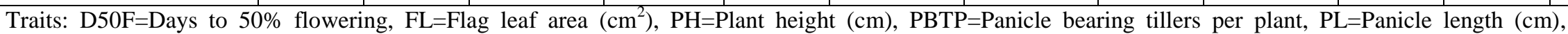
$\mathrm{SP}=$ Spikelets per panicle, $\mathrm{GP}=$ Grains per panicle, $\mathrm{SF}=$ Spikelet fertility $(\%), \mathrm{TW}=$ Test weight $(\mathrm{g}), \mathrm{BYP}=$ Biological yield per plant $(\mathrm{g}), \mathrm{HI}=\mathrm{Harvest}$ index $(\%)$ and $\mathrm{GYP}=$ Grain yield per plant $(\mathrm{g})$

$@=$ Negative value

***. Significant at $5 \%$ and $1 \%$ probability level, respectively 
Table.2 Estimates of general combining ability (gca) effects of parents for 12 traits in rice under salt affected soil

\begin{tabular}{|c|c|c|c|c|c|c|c|c|c|c|c|c|}
\hline Parent & D50F & FL & $\mathbf{P H}$ & PBTP & PL & SP & GP & SF & BYP & H.I. & TW & GYP \\
\hline \multicolumn{13}{|c|}{ Tester } \\
\hline CSR 28 & -0.08 & -0.08 & $-0.98 * *$ & $-0.63 * *$ & $-0.81 * *$ & $-12.44 * *$ & $-11.56 * *$ & -0.18 & 0.34 & -0.08 & $-0.48 * *$ & 0.02 \\
\hline IRRI123 & 0.47 & $1.37 * *$ & $5.46 * *$ & 0.33 & $1.07 * *$ & $7.25 * *$ & $6.25 * *$ & -0.09 & $2.66 * *$ & -0.07 & $0.34 * *$ & $1.07 * *$ \\
\hline FL-478 & -0.39 & $-1.30 * *$ & $-4.48 * *$ & 0.29 & -0.26 & $5.19 * *$ & $5.31 * *$ & 0.27 & $-3.01 * *$ & 0.15 & $0.14^{* *}$ & $-1.09 * *$ \\
\hline SE(g) tester & 0.24 & 0.17 & 0.32 & 0.23 & 0.19 & 0.49 & 0.48 & 0.24 & 0.19 & 0.14 & 0.05 & 0.09 \\
\hline SE(gi-gj) tester & 0.35 & 0.24 & 0.45 & 0.32 & 0.28 & 0.70 & 0.68 & 0.34 & 0.28 & 0.21 & 0.07 & 0.12 \\
\hline CD5\% & 0.49 & 0.34 & 0.63 & 0.46 & 0.39 & 0.99 & 0.96 & 0.49 & 0.39 & 0.29 & 0.10 & 0.18 \\
\hline CD1\% & 0.65 & 0.45 & 0.84 & 0.61 & 0.52 & 1.31 & 1.28 & 0.65 & 0.52 & 0.39 & 0.13 & 0.24 \\
\hline \multicolumn{13}{|c|}{ Line } \\
\hline IR12T193 & $-1.09 *$ & 0.01 & $4.31 * *$ & $1.14^{*}$ & $0.88^{*}$ & $5.25^{* *}$ & $3.44 * *$ & -0.72 & $8.70 * *$ & $1.59 * *$ & $-1.01 * *$ & $4.72 * *$ \\
\hline IR12T127 & 0.58 & 0.08 & $4.60 * *$ & -0.05 & 0.49 & $-8.53 * *$ & $-7.67 * *$ & 0.00 & 0.32 & -0.34 & $-0.57 * *$ & 0.01 \\
\hline NDRK 50031 & -0.27 & 0.05 & $-4.42 * *$ & -0.87 & $1.34 * *$ & $3.36 * *$ & $3.89 * *$ & 0.87 & $-1.07 * *$ & $-2.12 * *$ & $0.47 * *$ & $-1.48 * *$ \\
\hline NDRK 50036 & -0.53 & $-3.00 * *$ & -1.20 & 0.02 & -0.49 & 0.47 & 0.67 & -0.40 & -0.64 & $0.75^{*}$ & $-0.23 *$ & -0.02 \\
\hline NDRK 50037 & $1.49 * *$ & $-2.38 * *$ & $-3.22 * *$ & -0.27 & $-0.95 *$ & $-12.64 * *$ & $-12.89 * *$ & $-1.20 *$ & 0.23 & $-0.61 *$ & $1.79 * *$ & $-0.40 *$ \\
\hline NDRK 50051 & 0.02 & $1.45^{* *}$ & $2.86 * *$ & 0.36 & 0.59 & $-3.64 * *$ & $-4.33 * *$ & -0.78 & $2.25 * *$ & 0.30 & $0.54 * *$ & $0.95 * *$ \\
\hline NDRK 50036 & $-1.16^{*}$ & $-1.59 * *$ & $-3.34 * *$ & $-1.33^{* *}$ & 0.04 & $-2.75^{* *}$ & $-4.67 * *$ & $-1.41 * *$ & $-7.61 * *$ & -0.02 & $-1.53 * *$ & $-3.06^{* *}$ \\
\hline NDRK 50058 & 0.48 & -0.46 & $-4.40 * *$ & -0.67 & -0.49 & $-4.31 * *$ & $-3.56 * *$ & 0.33 & $-5.47 * *$ & -0.49 & $-0.96 * *$ & $-2.39 * *$ \\
\hline NDRK 50060 & 0.23 & $6.39 * *$ & $3.45 * *$ & 0.34 & $-0.86^{*}$ & $25.03 * *$ & $25.67 * *$ & $1.71 * *$ & $5.96 * *$ & $-1.17 * *$ & $1.22 * *$ & $1.70 * *$ \\
\hline NDRK 50063 & 0.53 & $2.21 * *$ & $4.34 * *$ & $1.70 * *$ & -0.09 & $-3.64 * *$ & $-3.00 * *$ & 0.39 & $-2.32 * *$ & $1.15^{* *}$ & 0.00 & $-0.43^{*}$ \\
\hline IR79156 & -0.76 & $-3.40 * *$ & $-7.28 * *$ & 0.73 & $-1.19 * *$ & 1.69 & $2.67 * *$ & $1.08 *$ & $-0.85 *$ & $0.78^{*}$ & $-1.62 * *$ & 0.11 \\
\hline Narendra.Usar 2009 & 0.48 & 0.64 & $4.30 * *$ & $-1.11 *$ & 0.72 & -0.31 & -0.22 & 0.10 & 0.49 & 0.19 & $1.90 * *$ & 0.28 \\
\hline SE(g,l) & 0.49 & 0.34 & 0.64 & 0.46 & 0.39 & 0.99 & 0.96 & 0.49 & 0.39 & 0.29 & 0.10 & 0.18 \\
\hline SE(gi-gj,l) & 0.70 & 0.48 & 0.90 & 0.65 & 0.56 & 1.40 & 1.37 & 0.69 & 0.56 & 0.42 & 0.14 & 0.25 \\
\hline CD5\% & 0.99 & 0.68 & 1.27 & 0.92 & 0.79 & 1.98 & 1.93 & 0.98 & 0.79 & 0.59 & 0.20 & 0.36 \\
\hline CD1\% & 1.31 & 0.90 & 1.69 & 1.22 & 1.05 & 2.63 & 2.56 & 1.30 & 1.05 & 0.78 & 0.26 & 0.48 \\
\hline
\end{tabular}

Traits: D50F=Days to $50 \%$ flowering, FL=Flag leaf area $\left(\mathrm{cm}^{2}\right), \mathrm{PH}=\mathrm{Plant}$ height $(\mathrm{cm})$, PBTP=Panicle bearing tillers per plant, PL=Panicle length $(\mathrm{cm})$, $\mathrm{SP}=$ Spikelets per panicle, $\mathrm{GP}=\mathrm{Grains}$ per panicle, $\mathrm{SF}=$ Spikelet fertility $(\%), \mathrm{TW}=$ Test weight $(\mathrm{g})$, BYP= Biological yield per plant $(\mathrm{g})$, HI=Harvest index $(\%)$ and $\mathrm{GYP}=$ Grain yield per plant $(\mathrm{g})$

$@=$ Negative value*,**. Significant at $5 \%$ and $1 \%$ probability level, respectively. 
Table.3 Estimates of specific combining ability (sca) effects of crosses for 12 traits in rice under salt affected soil

\begin{tabular}{|c|c|c|c|c|c|c|c|c|c|c|c|c|}
\hline Cross & D50F & FL & $\mathbf{P H}$ & PBTP & PL & SP & GP & SF & BYP & HI & TW & GYP \\
\hline $\mathrm{L} 01 \times \mathrm{T} 01$ & 0.02 & 0.68 & $7.97 * *$ & 0.31 & $1.93 * *$ & $14.56 * *$ & $15.56 * *$ & 1.66 & $1.58 *$ & -0.48 & 0.19 & 0.23 \\
\hline $\mathrm{L} 01 \times \mathrm{T} 02$ & -0.06 & $-1.60 * *$ & $-2.61 *$ & $1.85 *$ & -1.06 & $-10.14 * *$ & $-10.25^{* *}$ & -0.93 & $-2.11 * *$ & -0.31 & $-0.49 * *$ & $-0.88 * *$ \\
\hline $\mathrm{L} 01 \times \mathrm{T} 03$ & 0.04 & 0.92 & $-5.36 * *$ & $-2.17 * *$ & -0.87 & $-4.42 *$ & $-5.31 * *$ & -0.73 & 0.53 & 0.79 & 0.30 & $0.65^{*}$ \\
\hline $\mathrm{L} 02 \times \mathrm{T} 01$ & -0.61 & $-1.87 * *$ & -0.35 & $1.81 *$ & $1.68 *$ & $13.00 * *$ & $11.67 * *$ & 0.27 & $2.46^{* *}$ & $-1.48 * *$ & $-0.52 * *$ & 0.35 \\
\hline $\mathrm{L} 02 \times \mathrm{T} 02$ & 1.34 & $2.43 * *$ & 2.11 & -0.72 & -1.10 & 2.31 & 2.86 & 0.65 & $-3.50 * *$ & -0.15 & $-0.50 * *$ & $-1.61 * *$ \\
\hline $\mathrm{L} 02 \times \mathrm{T} 03$ & -0.74 & -0.57 & -1.75 & -1.08 & -0.57 & $-15.31 * *$ & $-14.53 * *$ & -0.92 & 1.04 & $1.63 * *$ & $1.02 * *$ & $1.26 * *$ \\
\hline $\mathrm{L} 03 \times \mathrm{T} 01$ & $1.75^{*}$ & $-3.27 * *$ & -0.43 & $3.42 * *$ & 0.17 & $3.78 *$ & $5.78 * *$ & 1.64 & $5.08 * *$ & $-1.20 *$ & $2.14 * *$ & $1.43^{* *}$ \\
\hline L03 × T02 & 0.27 & $1.60 * *$ & $-3.78 * *$ & -1.27 & -1.19 & $-17.58 * *$ & $-16.36^{* *}$ & -0.55 & $-2.11 * *$ & $1.42 * *$ & $1.62 * *$ & -0.15 \\
\hline $\mathrm{L} 03 \times \mathrm{T} 03$ & $-2.02 *$ & $1.67 * *$ & $4.20 * *$ & $-2.15 * *$ & 1.01 & $13.81 * *$ & $10.58 * *$ & -1.08 & $-2.97 * *$ & -0.22 & $-3.77 * *$ & $-1.28 * *$ \\
\hline $\mathrm{L} 04 \times \mathrm{T} 01$ & -1.06 & $3.02 * *$ & -2.15 & -1.20 & -0.41 & $-6.67 * *$ & $-6.00 * *$ & 0.47 & $-6.79 * *$ & $1.63 * *$ & $0.51 * *$ & $-2.05 * *$ \\
\hline $\mathrm{L} 04 \times \mathrm{T} 02$ & 1.06 & $-2.71 * *$ & $2.26 *$ & $-3.05 * *$ & -0.39 & $-16.03 * *$ & $-13.81 * *$ & 0.61 & $1.49 *$ & $-1.50 * *$ & $-1.34 * *$ & -0.07 \\
\hline L04 × T03 & 0.00 & -0.31 & -0.11 & $4.24 * *$ & 0.80 & $22.69 * *$ & $19.81 * *$ & -1.08 & $5.30 * *$ & -0.13 & $0.83 * *$ & $2.13^{* *}$ \\
\hline $\mathrm{L} 05 \times \mathrm{T} 01$ & -0.48 & $5.14 * *$ & $6.56 * *$ & 1.49 & 0.94 & $9.78 * *$ & $9.89 * *$ & 0.67 & $13.61 * *$ & -0.14 & $1.06 * *$ & $5.52 * *$ \\
\hline
\end{tabular}

\begin{tabular}{|c|c|c|c|c|c|c|c|c|c|c|c|c|}
\hline & & & & & & & & & & & \\
\hline $\mathrm{L} 05 \times \mathrm{T} 02$ & 0.17 & $-4.27 * *$ & $-8.48 * *$ & $-1.72 *$ & -1.04 & -2.58 & -2.25 & 0.05 & $-9.24 * *$ & $1.75 * *$ & $-1.69 * *$ & $-3.06 * *$ \\
\hline $\mathrm{L} 05 \times \mathrm{T} 03$ & 0.32 & -0.87 & 1.91 & 0.23 & 0.09 & $-7.19 * *$ & $-7.64 * *$ & -0.72 & $-4.37 * *$ & $-1.61 * *$ & $0.64 * *$ & $-2.46 * *$ \\
\hline $\mathrm{L} 06 \times \mathrm{T} 01$ & $2.13 *$ & 0.47 & $-5.18 * *$ & -1.47 & -0.28 & $-8.56 * *$ & $-5.33 * *$ & $1.79 *$ & $-7.74 * *$ & 0.58 & $-1.56 * *$ & $-2.92 * *$ \\
\hline $\mathrm{L} 06 \times \mathrm{T} 02$ & -1.13 & -0.89 & $6.75 * *$ & 0.86 & 0.39 & $10.75 * *$ & $5.86 * *$ & $-2.20 *$ & $3.30 * *$ & $-2.46^{* *}$ & -0.22 & 0.09 \\
\hline $\mathrm{L} 06 \times \mathrm{T} 03$ & -1.00 & 0.42 & -1.57 & 0.60 & -0.11 & -2.19 & -0.53 & 0.41 & $4.44 * *$ & $1.88^{* *}$ & $1.78 * *$ & $2.83 * *$ \\
\hline $\mathrm{L} 07 \times \mathrm{T} 01$ & $-1.76^{*}$ & $1.21 *$ & $3.92 * *$ & 1.19 & -0.15 & -0.78 & -0.33 & -0.25 & $2.39 * *$ & 0.33 & $0.40^{*}$ & $1.49 * *$ \\
\hline $\mathrm{L} 07 \times \mathrm{T} 02$ & 0.75 & $1.32 *$ & $3.81 * *$ & 0.23 & 0.94 & $7.86 * *$ & $4.86 * *$ & -1.44 & 0.24 & -0.53 & $1.88^{* *}$ & -0.59 \\
\hline $\mathrm{L} 07 \times \mathrm{T} 03$ & 1.01 & $-2.52 * *$ & $-7.73 * *$ & -1.42 & -0.80 & $-7.08 * *$ & $-4.53 * *$ & 1.70 & $-2.63 * *$ & 0.20 & $-2.29 * *$ & $-0.89 * *$ \\
\hline $\mathrm{L} 08 \times \mathrm{T} 01$ & -0.72 & 0.45 & $5.62 * *$ & 0.26 & 0.32 & $4.78 * *$ & 2.89 & -1.22 & -0.22 & $-1.57 * *$ & $-0.57 * *$ & $-0.79 *$ \\
\hline $\mathrm{L} 08 \times \mathrm{T} 02$ & -1.52 & $-2.61 * *$ & $-12.16^{* *}$ & -1.19 & -0.22 & 0.75 & 0.75 & -0.01 & $-3.67 * *$ & $-1.04 *$ & $-0.87 * *$ & $-1.77 * *$ \\
\hline $\mathrm{L} 08 \times \mathrm{T} 03$ & $2.24 *$ & $2.15 * *$ & $6.54 * *$ & 0.94 & -0.10 & $-5.53 * *$ & $-3.64 *$ & 1.23 & $3.90 * *$ & $2.60 * *$ & $1.44 * *$ & $2.56 * *$ \\
\hline $\mathrm{L} 09 \times \mathrm{T} 01$ & $-1.75^{*}$ & 0.63 & $4.80 * *$ & -0.58 & $-2.65 * *$ & $-38.22 * *$ & $-38.67 * *$ & $-2.97 * *$ & $1.98^{* *}$ & -0.52 & $-0.67 * *$ & 0.50 \\
\hline L09 × T02 & 0.77 & $3.43 * *$ & $7.35 * *$ & $1.75^{* *}$ & 1.01 & $15.42 * *$ & $14.86^{* *}$ & 0.89 & $3.99 * *$ & 0.77 & $1.02 * *$ & $2.16 * *$ \\
\hline L09 × T03 & 0.99 & $-4.05 * *$ & $-12.14 * *$ & -1.17 & $1.64 *$ & $22.81 * *$ & $23.81 * *$ & $2.08 *$ & $-5.97 * *$ & -0.25 & -0.34 & $-2.65 * *$ \\
\hline
\end{tabular}


Int.J.Curr.Microbiol.App.Sci (2017) 6(12): 2108-2120

\begin{tabular}{|c|c|c|c|c|c|c|c|c|c|c|c|c|}
\hline $\mathrm{L} 10 \times \mathrm{T} 01$ & $1.99 *$ & $-4.21 * *$ & $-7.83 * *$ & $-2.88 * *$ & $-1.83 * *$ & $3.78 *$ & 1.67 & -1.62 & $-9.19 * *$ & 0.57 & $-2.81 * *$ & $-3.55 * *$ \\
\hline $\mathrm{L} 10 \times \mathrm{T} 02$ & -0.91 & 0.53 & $3.45 * *$ & -0.38 & -0.16 & $-11.58 * *$ & $-7.81 * *$ & $1.89 *$ & $4.18 * *$ & -0.30 & $1.41 * *$ & $1.60 * *$ \\
\hline $\mathrm{L} 10 \times \mathrm{T} 03$ & -1.08 & $3.68 * *$ & $4.38 * *$ & $3.26 * *$ & $1.99 * *$ & $7.81 * *$ & $6.14 * *$ & -0.27 & $5.02 * *$ & -0.26 & $1.40 * *$ & $1.95^{* *}$ \\
\hline $\mathrm{L} 11 \times \mathrm{T} 01$ & $1.90 *$ & $-4.27 * *$ & $-15.81 * *$ & $-1.91 *$ & -0.92 & $-9.89 * *$ & $-8.00 * *$ & 1.10 & $-5.84 * *$ & $1.27 *$ & $0.80 * *$ & $-1.85 * *$ \\
\hline $\mathrm{L} 11 \times \mathrm{T} 02$ & -1.08 & $4.29 * *$ & $5.52 * *$ & $2.53 * *$ & $2.38 * *$ & $16.75^{* *}$ & $15.86^{* *}$ & 0.07 & $9.96 * *$ & $1.50 * *$ & $0.65 * *$ & $4.96^{* *}$ \\
\hline $\mathrm{L} 11 \times \mathrm{T} 03$ & -0.82 & -0.02 & $10.29 * *$ & -0.63 & $-1.46^{*}$ & $-6.86 * *$ & $-7.86 * *$ & -1.16 & $-4.12 * *$ & $-2.76 * *$ & $-1.45 * *$ & $-3.11 * *$ \\
\hline $\mathrm{L} 12 \times \mathrm{T} 01$ & -1.40 & $2.02 * *$ & $2.88^{*}$ & -0.44 & 1.20 & $14.44 * *$ & $10.89 * *$ & -1.53 & $2.69 * *$ & 1.02 & $1.05 * *$ & $1.65^{* *}$ \\
\hline $\mathrm{L} 12 \times \mathrm{T} 02$ & 0.35 & $-1.52^{*}$ & $-4.23 * *$ & 1.10 & 0.44 & $4.08 *$ & $5.42 * *$ & 0.98 & $-2.53 * *$ & 0.85 & $-1.47 * *$ & $-0.67 *$ \\
\hline L12 x T03 & 1.05 & -0.50 & 1.35 & -0.66 & $-1.64 *$ & $-18.53 * *$ & $-16.31 * *$ & 0.55 & -0.16 & $-1.87 * *$ & $0.43^{*}$ & $-0.97 * *$ \\
\hline $\mathrm{SE}(\mathrm{Sij})$ & 0.86 & 0.59 & 1.11 & 0.80 & 0.68 & 1.72 & 1.67 & 0.85 & 0.68 & 0.51 & 0.17 & 0.31 \\
\hline SE(Sij-Skl) & 1.21 & 0.83 & 1.57 & 1.13 & 0.97 & 2.34 & 2.37 & 1.20 & 0.97 & 0.72 & 0.24 & 0.44 \\
\hline CD5\% & 1.72 & 1.18 & 2.22 & 1.60 & 1.37 & 3.44 & 3.35 & 1.70 & 1.37 & 1.03 & 0.35 & 0.63 \\
\hline CD1\% & 2.27 & 1.56 & 2.94 & 2.11 & 1.82 & 4.56 & 4.45 & 2.25 & 1.82 & 1.36 & 0.46 & 0.84 \\
\hline
\end{tabular}

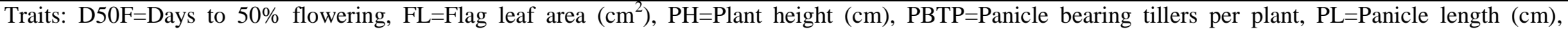
$\mathrm{SP}=$ Spikelets per panicle, $\mathrm{GP}=$ Grains per panicle, $\mathrm{SF}=$ Spikelet fertility $(\%), \mathrm{TW}=$ Test weight $(\mathrm{g}), \mathrm{BYP}=$ Biological yield per plant $(\mathrm{g}), \mathrm{HI}=\mathrm{Harvest}$ index $(\%)$ and $\mathrm{GYP}=$ Grain yield per plant $(\mathrm{g})$

Note: L01=IR12T193, L02=IR12T127, L03=NDRK 50031, L04 =NDRK 50036, L05= NDRK 50037, L06= NDRK 50051, L07= NDRK 50055, L08= NDRK 50058,L09= NDRK 50060, L10= NDRK 50063, L11= IR79156 and L12= Narendra Usar 2009

T01 $=$ CSR 28, T02 $=$ IRRI 123 and T03 $=$ FL $478^{*}, * *$. Significant at $5 \%$ and $1 \%$ probability level, respectively. 
The second ranged good general combiner for grain yield per plant, NDRK 50060 was found to be good general combiner for flag leaf area, spikelets per panicle, grains per panicle, spikelet fertility, biological yield per plant and test weight but it was poor general combiner for early flowering, plant height, panicle length, panicle bearing tillers per plant and harvest index. The third ranking parent, IRRI123 also possessed significant gca effects for flag leaf aera, panicle length, spikelets per panicle, grains per panicle biological yield per plant, and 1000- grain weight in desirable direction and days to $50 \%$ flowering short stature, panicle bearing tillers per plant, spikelet fertility and harvest index in undesirable direction. The parent, NDRK 50051 appeared as good general combiner for flag leaf area, biological yield per plant and harvest index besides grain yield per plant and poor general combiner for early flowering, short stature, panicle bearing tillers per plant, spikelets per panicle, test weight and spikelet fertility. The four parents showing positive and significant gca effects for grain yield and other important traits as mentioned above, may serve as valuable parents for hybridization programme or multiple crossing programme for obtaining high yielding pure line or hybrid varieties for salt affected or sodic soils. Some other lines identified as good general combiners in desirable direction for characters other than grain yield per plant are also listed in Table 2. These parents may also be recommended for exploitation in hybridization programme as donor of component characters for which they emerged as good general combiner in spite of being average or poor general combiner for grain yield.

It is evident from Table 2, that most of the lines showing significant positive gca effects for grain yield per plant also exhibited positive and significant gca effects for some of the important yield components such as biological yield per plant, 1000- grain weight, spikelet fertility, spikelets per panicle and panicle bearing tillers per plant. This indicated that the significant gca effects for grain yield in positive direction resulted from similar gca effects of some other yield components suggesting that the combining ability for grain yield was influenced by the combining ability of its component traits. Therefore, simultaneous improvement in important yield components and other associated traits along with grain yield may be better approach for enhancing yield potential in rice. Similar results have also been reported by Verma et al., (2003); Verma and Srivastava (2004); Saleem et al., (2010); Bagheri and Jelodar (2010) and Saidaiah et al.,(2011); Sanghara and Hussain (2012); Tiwari et al., (2014); S. Prasad et al., (2015) and Archana Devi et al., (2017).

\section{Specific combining ability effect}

The specific combining ability (sca) effects, which are supposed to be manifestation of non-additive components of genetic variance, are highly valuable for discrimination of crosses for their genetic worth as breeding materials. The estimates of sca effects of 36 crosses for 12 characters are given in Table 3.

In present study, none of the crosses showed significant sca effects in desirable direction for all the characters. Several crosses exhibited significant and desirable sca effects for one or more characters but none of them emerged as good specific combination for more than nine characters. Five crosses, NDRK 50037 x CSR 28, IR79156 x IRRI123, NDRK $50051 \times$ FL 478, NDRK 50058 x FL 478, and NDRK $50060 \times$ IRRI123 showed significant and positive sca effects for grain yield per plant as well as some other yield components. The cross, NDRK 50037 x CSR 28 for highest positive and significant sca effect for grain yield per plant showed 
significant and desirable sca effects for flag leaf area and biological yield per plant. The second ranking cross, IR79156 x IRRI123 having highest positive and significant sca effects for grain yield per plant also recorded significant sca effects in desirable direction for flag leaf area, panicle bearing tillers per plant, panicle length, spikelet per panicle and biological yield per plant. The third ranking cross for significant and positive sca effects for grain yield per plant was NDRK $50051 \mathrm{x}$ FL 478 which exhibited significant and desirable sca effects for harvest index and test weight. The fourth ranking cross for significant and positive sca effects for grain yield per plant (NDRK 50058 x FL 478) exhibited significant and desirable sca for harvest index and test weight. The fifth ranking cross in this context, NDRK $50060 \mathrm{x}$ IRRI123 recorded significant sca effects in desirable direction for flag leaf and spikelet per panicle.

The above five crosses having significant and positive sca effects for grain yield per plant also showed positive and desirable significant sca effects for some other characters, viz., flag leaf area, spikelet per panicle and biological yield per plant. This suggested that manifestation of sca effects for grain yield is related with higher sca effects for important yield components. In general, the crosses showing significant and desirable sca effects were associated with better per se performance for respective traits. However, the crosses having high sca effects in desirable direction did not always have high mean performance for the character in question. Thus, the sca effect of the crosses may not be directly related to their per se performance. This may be attributed to the fact that per se performance is a realized value, whereas, sca effect is an estimate of $F_{1}$ performance over parental one. Therefore, both per se performance along with sca effects should be considered for evaluating the superiority of a cross although the former may be more important if development of $F_{1}$ hybrids is the ultimate objective.

The critical examination of Table 3 would reveal that the crosses exhibiting high order significant and desirable sca effects for different characters involved parents having all types of combinations of gca effects such as high $\times$ high $(\mathrm{H} \times \mathrm{H})$, high $\times$ average $(\mathrm{H} \times$ A), high $\times$ low $(\mathrm{H} \times \mathrm{L})$, average $\times$ average $(\mathrm{A}$ $\times \mathrm{A})$, average $\times$ low $(\mathrm{A} \times \mathrm{L})$ and low $\times$ low $(\mathrm{L}$ $\times$ L) general combiner parents. The foregoing observation clearly indicated that there was no particular relationship between positive and significant sca effects of crosses with gca effects of their parents for the characters under study. Saleem et al., (2010), Saidaiah et al., (2011); Dwivedi and Pandey (2012); Sanghara and Hussain (2012) and Tiwari et $a l$. , (2014) have also reported similar findings. High $\times$ high, high $\times$ average and average $\times$ average crosses give transgressive segregants and selection in early generation would be advantageous for development of pure lines as there are involvement of additive gene action, whereas, crosses having high $\times$ low, average $\times$ low and low $\times$ low general combining parents are suggested for heterosis breeding as their inheritance are controlled by non-additive and epistatic gene action.

\section{References}

Anonymous (2001). Rice research and production in the $21^{\text {st }}$ century Garmene Refernce ID 8380.

Anonymous. (2014). U.P. Directorate of Agricultural Statistics Reports.

Archana Devi; Kumari, Preeti; Dwivedi, Ranjan; Dwivedi, Saket; Verma, O.P., Singh, P.K. and Dwivedi, D.K. (2017). Gene action and combining ability analysis for yield and yield contributing traits in rice (Oryza sativa L.) over environment. Journal of 
Pharmacognosy and Phytochemistry. 6(3): 662-671

Ashish., Srivastava, K., Chauhan, M.P., Maurya, K.N., Verma, O.P., Prasad, S; Mishra, S.K. and Mishra, S. (2016) Studies on genetic variability, haritability and gene advance in rice (Oryza sativa L.) International J. of Sci. and Res.

Bagheri, N. and Jelodar, N.B. (2010). Heterosis and combining ability analysis for yield and related-yield traits in hybrid rice, International J. of Bio., 2 (2): 222-231.

Basavaraja, T., Asif, M., Mallikarjun, S. K. and Gangaprasad, S. (2013). Variability, heritability and genetic advance for yield and yield attributing characters in different local rice (Oryza sativa L.) cultivars. Asian J. of Bio Sci., 8 (1):6062.9 .

Dwivedi, D.K. and Pandey, M.P. (2012). Gene action and heterosis for yield and associated traits in Indica and Tropical Japonica crosses of rice (Oryza sativa L.) Involving Wide Compatibility Gene(s). International Journal of Plant Breeding and Genetics, 6:140-150.

FAO, Extent of salt affected soils www.fao.org/soils-portal/soilmanagement-of-someproblem-soil/saltaffected soils/more-information-on-salt affected-soils/en [last accessed 3 Dec. 2014].

Gopikannan, M. and Ganesh, S. K. (2013). Investigation on combining ability and heterosis for sodicity tolerance in rice (Oryza sativa L.). African J. of Agril. Res., 8 (32):4326-4333.

Kempthorne, O. (1957). An Introduction to Genetical Statistics. John Wiley and Sons Inc. New York, pp. 468-471.

Kumar A. and Verma O. P. (2015).

Panwar, L.L. (2006). Character association and path analysis in rice (Oryza sativa L.). Ann. Agric. Res. 27(3):257-260.
Pradhan, S.K., Bose, L.K. and Meher, J. (2006). Studies on gene action and combining ability analysis in basmati rice. Journal of Central European Agriculture, 7 (2): 267-272.

Prasad, S., Verma, O.P., Treepathi, N., Ashish; Yadav, P.K. (2015). Combining ability for yields and its contributing traits in rice (Oryza sativa L.). International J. of Sci. and Res.

Punitha, D., Joel, A.J., Manonmani S. and Thiyagarajan, K. (2004). Combining ability for yield and its components in rice (Oryza sativa L.). Advances in Plant Sci., 17 (1): 345-348.

Saidaiah, P., Ramesha, M. S. and Kumar, S. S. (2011). Combining ability analysis for yield and yield component traits in rice (Oryza sativa L.), Progressive Agriculture. 11 (2): 293-297.

Saleem, M.Y., Mirza, J.I. and Haq, M.A. (2008). Heritability, genetic advance and heterosis in line $\mathrm{x}$ tester crosses of Basmati rice. J. Agric. Res., 46 (1): 1526.

Saleem, M.Y., Mirza, J.I. and Haq, M.A. (2010). Combining ability analysis of some morpho-physiological traits in Basmati rice, Pakistan Journal of Botany, 42 (5): 3113-3123.

Sanghera, G. S. and Waseem Hussain (2012). Heterosis and combining ability estimates using Line $\mathrm{x}$ tester analysis to develop rice hybrids for temperate conditions. Notulae Scientia Biologicae, 4: (3): 131-142.

Seyom, M., Alamerew, S., Bantee,K. (2012). Genetic variability, heritability, correlation coefficient and path analysis for yield and yield related traits in upland rice (Oryza sativa L.). Journal of plant science, 7 (1): 13-22.

Subaiah, S.V. (2006). Several options being tapped. The Hindu Survey of Indian Agriculture, pp. 50-54.

Tiwari, G. C. Jatav, N. K. (2014) Combining 
ability analysis for grain yield and its related characters in rice. Trends in Biosciences; 7(13):1444-1448.

Verma O. P. and Srivastava H. K. (2004). Genetic component and combining ability analysis in relation to heterosisfor yield and associated traits using three diverse rice-growing ecosystems. Field Crop Res. 88:91-102.

Verma O. P., Santoshi, U.S. and Srivastava H. K. (2003) Governence of gene action and combining and ability for certain grain quality traits in three diverse rice (Oryza sativa L.) growing ecosystems. J. Sustain Agric. 22(4):63-78.

Verma, O. P., Singh, R. V., Dwivedi, J. L. and Prakash, N. (2006). Genetic analysis of yield and its components in rice. Oryza. 43 (1), 55-57.

Vijayalakshmi, B., Vijay, D., Raju, P.R.K. and Satyanarayana, P.V. (2008) Genetic divergence of qualitative and quantitative characters in lowland rice germplasm. Crop Research (Hisar), 36 $(1 / 3): 212: 214$

Vishwakarma, D.N., Vishwakarma, S.R., Verma, L.P. and Kanti Prasad. (2003). Combining ability analysis of some quantitative characters in rice. Ann. Pl. Soil Res., 5 (1): 72-75.

Wei, L., Chao, L.Z., Li, W.M.H., Jian, W. and Liang, Z. H. (2004). Heterotic ecotypes grouping of japonica rice by combining ability. Acta Agronomica Sinica, 30 (1): 66-72.

\section{How to cite this article:}

Maurya, S.P., O.P. Verma, P.K. Singh, A.K. Singh and Jyoti Verma. 2017. Identifying Superior Parents and Recombinants in Rice (Oryza sativa L.) under Salt Affected Soil. Int.J.Curr.Microbiol.App.Sci. 6(12): 2108-2120. doi: https://doi.org/10.20546/ijcmas.2017.612.241 